\title{
INTERNATIONAL ARBITRATION AS A SPONTANEOUS LEGAL ORDER
}

\author{
SONSOLES HUERTA DE SOTO* AND FABIO NÚÑEZ DEL PRADO**
}

Fecha de recepción: 20 de noviembre de 2019

Fecha de aceptación: 25 de septiembre de 2020

Resumen: El Individualismo Metodológico (o, si se prefiere, la praxeología) es imprescindible para entender los fenómenos sociales. La praxeología se debe aplicar no sólo al estudio del proceso social sino también al estudio de los distintos aspectos de este proceso, como son la Economía, el Derecho y las Instituciones. Por tanto, las ciencias sociales, incluyendo el Derecho (y dentro del mismo el Arbitraje Internacional) deben ser estudiadas desde el Individualismo Metodológico. Hasta ahora ha habido muy pocos intentos de construir una teoría jurídica del arbitraje. La falta de una teoría exhaustiva capaz de explicar el fundamento del Arbitraje puede tener resultados poco deseables, tanto respecto a su (mal) funcionamiento como respecto a su supervivencia futura. En este artículo argumentamos que la praxeología, como la ciencia que estudia la lógica de la acción humana, así como la teoría de la evolución espontánea de las instituciones, es la única metodología que puede explicar el Arbitraje internacional de forma integral.

El arbitraje internacional es una vía por la que las controversias internacionales se pueden resolver de forma definitiva, conforme al acuerdo de las partes, por terceros imparciales y privados, designados por o para las partes, y aplicando procedimientos jurídicos neutrales que brindan a las mismas el derecho de audiencia. Actualmente, es el principal mecanismo utilizado para resolver controversias internacionales que involucran a Estados, individuos, y/o corporaciones. El Arbitraje Internacional es además una institución jurídico-social de evolución espontánea.

Palabras clave: Escuela Austriaca de Economía, Individualismo Metodológico, Arbitraje Internacional, Orden Espontáneo de Mercado, Teoría Evolutiva de las Instituciones.

Clasificación JEL: K4, K19, K33

* LLM London School of Economics and Political Science. International Arbitration lawyer.

** LLM Yale Law School. International Associate Clifford Chance, Washington. 
Abstract: Methodological Individualism (or better, praxeology) is essential to understand social phenomena. Praxeology should be applied not only to the study of the social process but also to the study of the different aspects of this process, such as Economics, Law, and Institutions. Hence, social sciences, including the Law (and International Arbitration within it) should therefore be studied from Methodological Individualism.

There have been very few attempts to draw up a legal theory of arbitration. The lack of a comprehensive theory capable of explaining Arbitration's foundation may have undesired results, both with regard to its (mal-) functioning and its future survival. We argue in this paper that praxeology, as the science that studies the logic of human action, and the theory of the spontaneous evolution of institutions, is the only methodology that can explain International Arbitration integrally.

International arbitration is a means by which international disputes can be definitely resolved, pursuant to the parties' agreement, by impartial, non-public decision-makers, appointed by or for the parties, applying neutral judicial procedures that provide the parties an opportunity to be heard. Today it is the main mechanism for solving international disputes involving States, individuals, and/or corporations. International arbitration is also a social-juridical institution of spontaneous evolution.

Key Words: Austrian School of Economics, Methodological Individualism, International Arbitration, Spontaneous Market Order, Social Evolution of Institutions

JEL Classification: K4, K19, K33

\section{INTRODUCTION}

Throughout history there has been an endless debate between two streams of thought: iusnaturalism and positivism. Positivism affirms that it is only law what is written in a legal system. On the other hand, iusnaturalism argues that the origin of human rights does not reside in positive law, but rather in the nature of human beings, which is superior and precedent to any positive law. This natural law is the result of spontaneous evolution.

The study of the philosophy of law is essential because it allows us to understand the foundation of legal institutions. Only by 
understanding the nature of things it is possible to build solid and functional institutions. From that perspective, counting with a parameter that illuminates legal disciplines is essential.

One of the most captivating virtues of international arbitration is that one single arbitration can involve people with different nationalities, different cultures, different religions, different languages, different customs, and all with the precious purpose of peacefully solving a dispute. Although international arbitration has been one of the most important institutions for the defense of foreign investment and international commerce, the existence of a theory that explains the foundation of international arbitration has always been conspicuous by its absence.

In an international legal order such as international arbitration, the lack of a comprehensive theory capable of explaining its foundation may have undesired results, both with regard to its (mal-) functioning and its future survival. Each actor of international arbitration usually has a particular way of understanding the law that is conditioned by various factors. Hence, without an integral theory that explains the foundation of international arbitration, it is very easy to lose perspective. Both legislators and international trade operators are lacking of a theoretical north to guide them in the international arbitration arena.

There have been few attempts to construct a legal theory of arbitration. We will mention two of them, carried out by two reputed international arbitration lawyers: Jan Paulsson, with his book The Idea of Arbitration; and Emmanuel Gaillard with his book Legal Theory of International Arbitration. These books are a valid effort to understand the foundations of international arbitration, but they can be theoretically complemented and enriched with the postulates of the Austrian School of Economics.

The Austrian School of Economics is a school of thought that studies human action from individual freedom, and defends private initiative and entrepreneurial creativity rather than the institutional aggression or coercion of the State. The Austrian School of Economics is multidisciplinary and, notwithstanding its name, offers a way of understanding not only Economics, but society, the Law and ultimately the human being and human action. 
Arbitration is the most important Alternative Dispute Resolution Method (hereafter "ADR"). In the wide sense we can say that ADR refer to a series of processes that emerge for the resolution of disputes, in which the parties agree to make an effort to avoid the public courts of justice, but they cannot reach a solution by themselves and need the intervention of a third party. The appropriate approach from which ADR must be addressed and studied is individual freedom. ADR are the product of the exercise of private initiative in the dispute resolution sphere, and are the counterpart to dispute resolution via the public system offered by the State. Therefore, it is from the exercise of the entrepreneurial function in the dispute resolution sphere that ADR emerge. These alternative methods in part respond to the inefficiency of the public court system. ADR includes conciliation, mediation and arbitration.

Solving disputes through the coactive machinery of the State is inefficient as it poses both theoretical and practical shortcomings. With regard to the former, following Mises and Hayek, we know that it is impossible for any authority or authorities (public courts of justice) to coactively organize from above the administration of justice in an efficient and productive manner. This is known as the Theorem of the Impossibility of Socialism, which will be further explained below. In fact, any intent of organization from coative imposition is an obstacle that impedes the real coordination of the social process phenomena and its institutions. From a practical point of view, the shortcomings of the public court system are obvious. We can mention some of them, for example: (i) the lack of specialization, flexibility and adaptation of the judges; (ii) the high costs of the proceedings; (iii) the lack of motivation of the judges; (iv) the potential political partiality of the judges; (v) the frequent low quality of the decisions; (vi) the time inefficiency of the proceedings; (vii) or that the law applied in many cases does not respond well to the real needs and problems of the parties (this is in part due to the erroneous idea the judges have on how the law is formed-in a constructivist way via the legislative power rather than as a result of an evolutionary and spontaneous process). ${ }^{1}$

\footnotetext{
1 Tannehill, M.; Tannehill, L. (2011), pp. 1, 2. See also Huemer, M. (2019), pp. 539554.
} 
Drawing on diverse libertarian literature, we will argue that praxeology, as the science that studies the logic of human action, and the theory of the spontaneous evolution of institutions, is the only methodology that can explain International Arbitration integrally. In this regard, we will defend that the Austrian School of Economics is the school of thought that can explain the foundations of International Arbitration from an appropriate and coherent approach. In brief, we will contend that the Austrian paradigm offers the theoretical framework under which international arbitration must be understood, studied and analyzed.

II

\section{OVERVIEW OF INTERNATIONAL ARBITRATION}

Arbitration is today the principal private mechanism for solving international disputes involving States, individuals, and corporations. This is one of the consequences of the increased globalization of world trade and investment. ${ }^{2}$ It is undisputed that international arbitration has become the natural method of solving disputes in international transactions.

\section{Description of international arbitration}

International arbitration is a means by which international disputes can be definitively resolved, pursuant to the parties' agreement, by impartial, non-public decision-makers, appointed by or for the parties, applying neutral judicial procedures that provide the parties an opportunity to be heard. ${ }^{3}$

2 Blackaby, N. and Partasides, C., (2015), pp. 1.

3 Born, G., (2014), pp. 70. In this regard, Redfern and Hunter, see Blackaby, N. and Partasides, C., (2015), pp. 2, state that "arbitration is essentially a very simple method of resolving disputes. Disputants agree to submit their disputes to an individual whose judgment they are prepared to trust. Each puts its case to this decision maker, this private individual-in a word, this 'arbitrator'. He or she listens to the parties, considers the facts and the arguments, and makes a decision. That decision is final and binding on the parties-and it is final and binding because the parties have agreed that it should be, 
International arbitration is a hybrid. It begins as a private agreement between the parties. It continues by way of private proceedings, in which the agreements of the parties play a significant role. And arbitration ends with an award which, under the appropriate conditions, the courts of most countries of the world will recognize and enforce ${ }^{4}$ as if it were a final judicial ruling. The State recognizes and enforces, with the aid of its coercive power, the award that results from a completely private process of resolving disputes.

\section{a) International arbitration agreements}

\section{i. Foundation stone of international arbitration}

The foundation stone of modern international arbitration is the principle of party autonomy. This principle, present throughout the whole arbitral process, is particularly vibrant in the parties' agreement to arbitrate or arbitration agreement. This is the agreement by the parties to submit any disputes or differences between them to arbitration. ${ }^{5}$

rather than because of the coercive power of any state. Arbitration, in short, is an effective way of obtaining a final and binding decision on a dispute, or series of disputes, without reference to a court of law (although, because of national laws and international treaties such as the New York Convention, that decision will generally be enforceable by a court of law if the losing party fails to implement voluntarily)." Likewise, De Vries, (1982) pp. 42, 43 has defined arbitration as "a mode of resolving disputes by one or more persons who derive their power from the agreement of the parties and whose decision is binding upon them." Similarly, Reisman, W., (1997) pp. 1 has affirmed that arbitration is "is one of a number of techniques for resolving disputes between persons or legal entities without, at least in the first instance, repairing to and invoking the power of national courts." Poudret \& Besson (2007), pp. 3, have defined arbitration as "a device whereby the settlement of a question, which is of interest for two or more persons, is entrusted to one or more other persons - the arbitrator or arbitrators - who derive their powers from a private agreement, not from the authorities of a State, and who are to proceed and decide the case on the basis of such an agreement." Finally, Fouchard, Gaillard and Goldman in Gaillard, E. and Savage, J., (1999), pp. 9, have stated that "Arbitration is a private method of settling disputes, based on the agreement between the parties. Its main characteristic is that it involves submitting the dispute to individuals chosen, directly or indirectly, by the parties."

${ }^{4}$ Blackaby, N. and Partasides, C., (2015), pp. 27.

${ }^{5}$ Id. pp. 12. Additionally, Professor Born in Born, G., (2014), pp. 72, explains that "an international arbitration agreement is similar in some respects to a forum selection clause, in that it provides a contractual choice of a dispute resolution forum." 
As explained by Prof. Van den Berg, "obviously no arbitration is possible without its very basis, the arbitration agreement." 6 Thus, before there can be a valid arbitration, there must first be a valid agreement to arbitrate.

An international arbitration agreement is a contract in which two or more parties agree that a dispute which has arisen or which may arise between them shall be resolved by one or more arbitrators. $^{7}$

Article II (1) of the New York Convention ${ }^{8}$ refers to an agreement to arbitrate as including "an agreement in writing under which the parties undertake to submit to arbitration all or any differences which have arisen or may arise between them in respect of a defined legal relationship, whether contractual or not."

The most important purpose of an agreement to arbitrate is that of making it plain that the parties have indeed consented to resolve their disputes by arbitration. This consent is essential: without it, there can be no valid arbitration.

Consequently, the function of the arbitration agreement is twofold: (i) it establishes the obligation to arbitrate, and is also (ii) a basic source of the powers of the arbitral tribunal.

An 'agreement to arbitrate' is usually expressed in an arbitration clause in a contract. However, there is a second less common

In the words of the U.S. Supreme Court, "an agreement to arbitrate before a specialized tribunal is, in effect, a specialized kind of forum-selection clause that posits not only the situs of suit but also the procedure to be used in resolving the dispute. Scherk v. Alberto-Culver Co., 417 U.S. 506, 519 (U.S. S.Ct. 1974).

6 Van den Berg, A., (1981), pp. 144-45. In that regard, the tribunal of an ICC case affirmed that "arbitration is a consensual process and depends upon the existence of a valid agreement to arbitrate." Award in ICC Case No. 7929, XXV Y.B. Comm. Arb. 312, 316 (2000). Similarly, in the case Watkins-Johnson Co. v. Islamic Repub. of Iran, the tribunal stated that "there can be no doubt that arbitrations, whether international or between subjects of private law, derive their mandate and competence from the consent and agreement of the parties to the arbitral agreement; therefore, it is the parties' consent that determines the scope, limits and area of certitude of an arbitrator's authority and jurisdiction." Watkins-Johnson Co. v. Islamic Repub. of Iran, Award in IUSCT Case No. 429-370-1 of 28 July 1989, 22 Iran-US C.T.R. 218, 296 (1989) (Noori, J., dissenting).

7 Gaillard, E. and Savage, J., (1999), pp. 193.

8 Convention on the Recognition and Enforcement of Foreign Arbitral Awards, New York, 1958. 
type of arbitration agreement that is generally known as a 'submission agreement'. This agreement is executed once a dispute has arisen. ${ }^{9}$

It is a well stablished principle of international arbitration that the arbitration clause is independent and severable from the main contract in which it is included (principle of severability). The most important consequence of this principle is that the arbitration agreement can remain valid even if the main contract is found to be void.

\section{ii. Scope of the agreement to arbitrate}

Arbitration is based on the parties' consent to submit their disputes to private adjudication. This consent is expressed in the arbitration clause or agreement to arbitrate.

A legitimate question that may arise is: can the parties submit any dispute to arbitration? Most legal systems require that only matters over which the parties have freedom of contract can be submitted to arbitration. It is the law of each State the one that defines the limits to the freedom of contract (in Spanish 'materias de libre disposición'). These obviously include contractual issues, but gradually the boundaries to the freedom of contract are becoming more and more flexible. It is no matter of dispute that issues traditionally excluded from arbitration can now be submitted to private adjudication if both parties agree, for example, competition law or family law.

But, should there be any limits to the freedom of contract at all? Why does the legislator put limits to the freedom of contract? Generally speaking we can say that the limit to the parties' consent to arbitrate is the public interest. The State does not trust the parties privately adjudicating matters that are considered of public interest. But, does this have a real reason of being? The reason why in some cases disputes are solved through private institutions such as arbitration and in other cases compliance of contractual obligations and the Law is established coactively by the State through its courts is not so much a juridical or economic question but rather a political question ${ }^{10}$.What is exactly the public interest? And most

\footnotetext{
${ }^{9}$ Gaillard, E. and Savage, J., (1999), pp. 9.

10 Rojas, R.M.; 2015; p. 243.
} 
importantly, why should the State draw any limits to the parties' consent to arbitrate?

Article V (2) (a) of the New York Convention states that:

"Article V.- 2. Recognition and enforcement of an arbitral award may also be refused if the competent authority in the country where recognition and enforcement is sought finds that:

(a) The subject matter of the difference is not capable of settlement by arbitration under the law of that country."

The New York Convention provides States with discretion to decide the scope of arbitrability of their own legal system. Therefore, in accordance to International Law, States are entitled to expand arbitrability to administrative, family, consumer, antitrust or criminal disputes to arbitration without inconvenience.

In our opinion, prohibiting the parties from submitting their administrative, family, consumer, competition, criminal or any kind of disputes to arbitration is an illegitimate political restriction to party autonomy and freedom of contract. Restricting the parties' will to decide how their disputes should be resolved regardless of the type-implies assuming that the State knows better than the parties how their disputes should be resolved. This is absurd. No one will know better than the parties themselves the best way to resolve their disputes, not even the State. Allowing the State to decide what is better for the parties is an example of Hayek's fatal conceit. Hayek condemns the intellectual arrogance of the human reason to design society (and the law) from above coactively. In Hayek's own words: “...the fundamental attitude of true individualism is one of humility toward the process by which mankind has achieved things which have not been designed or understood by any individual and are indeed greater than individual minds. The greater question at this moment is whether man's mind will be allowed to continue to grow as part of this process or whether human reason is to place itself in chains of its own making."11 Moreover, "public interest' is an opportunistic and vague concept oftenly used by

${ }^{11}$ Hayek, F.A. (1948), pp. 32. 
the State as an instrument to carry out its own policies in detriment of individual freedom.

A legal order in which individuals are free to resort to arbitration -regardless of the type of dispute- is more respectful, not only to freedom of contract and party autonomy, but also, we sustain, to the rule of law. The rule of law must be ultimately based in freedom, as an intrinsic element of the human nature, but not in any system of coercion or aggression such as the State.

\section{b) International arbitration procedures}

As we have mentioned before, the agreement to arbitrate has procedural effects, it puts in place private proceedings for resolving a dispute.

Party autonomy is the guiding principle in determining the procedure to be followed in an international arbitration. Consequently, one of the most fundamental characteristics of international arbitration is the parties' freedom to agree upon the arbitral procedure. $^{12}$

The New York Convention recognizes the central role of the parties' autonomy to tailor the arbitration procedure, and prescribes for the non-recognition of awards following proceedings that failed to respect the parties' agreed procedures. ${ }^{13}$

In this regard, article $\mathrm{V}(1)(\mathrm{d})$ permits non-recognition of an award if:

"Article V (1) (d).- The composition of the arbitral authority or the arbitral procedure was not in accordance with the agreement of

12 In this sense, Professor Born in Born, G., (2014), pp. 2130-2131 has stated that "this principle is acknowledged in and guaranteed by the New York Convention and other major international arbitration conventions; it is guaranteed by arbitration statutes in virtually all jurisdictions; and it is contained in and facilitated by the rules of most arbitral institutions. The principle of the parties' procedural autonomy is qualified only by mandatory requirements of fundamental procedural fairness, which are narrowly limited in scope under most international and national arbitration regimes."

${ }^{13}$ Id. pp. $2130-2131$. 
the parties, or, failing such agreement, was not in accordance with the law of the country where the arbitration took place."

Parties are afforded broad discretion over the arbitral procedures in order to fashion such procedures to the circumstances of their individual dispute. This allows parties to design procedures that meet their needs and expectations. ${ }^{14}$

Due to procedural autonomy, the parties are entitled, for example, to select the institutional rules that will govern the arbitration, establish the number of memorials or briefs that will be submitted, create a calendar and set the deadlines, decide how the hearing will be conducted, decide the maximum number of pages a submission can have, as well as many other important procedural decisions.

In this regard, Cuniberti has affirmed that:

"The third advantage that arbitration offers is procedural flexibility. The parties have the power to design the arbitral process. They can determine the procedural rules which will be applicable during the arbitration. This procedural flexibility can be used in different ways. The parties may shape a process which is only slightly different from the process of the court which would have decided the dispute in the absence of an agreement to arbitrate. But the parties may also wish to shape a process which will be very different from the alternate judicial process, so much so that it may become almost as important an advantage as the fairness of the arbitral process." 15

In the absence of agreement between the parties, the arbitral tribunal has broad discretion to take these decisions, which will be binding on the parties. ${ }^{16}$

${ }^{14}$ Unlike procedural domestic systems, the arbitral procedure is very flexible. Substantial deference is afforded to parties' procedural autonomy and arbitrators' procedural discretion. That deference arises from the fundamental importance of party autonomy to the arbitral process. Id. pp. 2180.

15 Cuniberti, G., (2009), pp. 13.

${ }^{16}$ An arbitration will generally be commenced by a request for arbitration, followed by an answer, enabling each of the parties to present its initial claims. 
One of the essential features of the arbitral proceedings is that arbitrators must guarantee the parties an opportunity to be heard, as well as equality of treatment. The UNCITRAL Model Law ${ }^{17}$ is representative of the exigency to treat parties with procedural fairness. In effect, article 18 of the Model Law requires that "the parties shall be treated with equality and each party shall be given a full opportunity of presenting his case." This explains why article 18 is sometimes referred to as the "Magna Carta" of the arbitral procedure. ${ }^{18}$

\section{c) International arbitration awards}

Parties who go to the trouble and expense of taking their disputes to international arbitration do so in the expectation that the arbitral procedure will lead to an award. They also expect that the award will be final, binding and enforceable. ${ }^{19}$

There is no internationally accepted definition of the term 'award'. No definition is to be found in the main international conventions dealing with arbitration. ${ }^{20}$

In the broad sense, 'award' can be described as a final decision which disposes of all issues submitted to the arbitral tribunal and

17 UNCITRAL Model Law on International Commercial Arbitration, 1985.

18 UNCITRAL, Report of the Secretary- General on the Analytical Commentary on Draft Text of A Model Law on International Commercial Arbitration, U.N. Doc. A/ CN.9/264, Art 19, 17 (1985).

19 Blackaby, N. and Partasides, C., (2015), pp. 501.

${ }^{20}$ In this regard, Professor Di Pietro in Di Pietro (2008), pp. 139, affirms that "there is virtually no express guidance from either international conventions or national arbitration legislation as to what constitutes an arbitral award. Although its title is directed toward the recognition and enforcement of 'arbitral awards,' the New York Convention contains no express definition of the terms 'arbitral award'. Virtually all arbitration legislation also omits language defining the terms 'arbitral award'. The drafters of the original 1985 UNCITRAL Model Law considered proposals for a definition of "award," including a proposed definition that would have provided: "'Award' means a final award which disposes of all issues submitted to the arbitral tribunal and any other decisions of the arbitral tribunal which finally determines any question of substance or the question of its competence or any other question of procedure but, in the latter case, only if the arbitral tribunal terms its decision an award." Report of the Working Group on International Contract Practices on the Work of Its Seventh Session, U.N. Doc. A/CN.9/246, XV Y.B. UNCITRAL 189, 211 (1984). 
any other decision of the arbitral tribunal which finally determines any question of substance or the question of its competence. ${ }^{21}$ Consequently, the term 'final award' is usually reserved for an award that completes the mission of the arbitral tribunal. ${ }^{22}$ As a result, once a final award is made, the tribunal becomes functus officio and its mandate generally comes to an end. ${ }^{23}$

An arbitral award must comply with the following features ${ }^{24}$ :

a) First, an award is made by the arbitrators. Decisions taken by an arbitral institution are not arbitral awards.

b) Second, an award resolves a dispute. Measures taken by arbitrators which do not decide the dispute either wholly or in part are not awards.

c) Third, an award is a binding decision. Decisions which only bind the parties on condition that they expressly accept them are not awards.

International arbitral awards are not "advisory" recommendations. They are, instead, final and binding legal instruments, generally having immediate legal effects and creating immediate legal rights and obligations for the parties. ${ }^{25}$ In other words, the arbitral award produces res judicata effects. The res judicata principle prescribes that a legal right or obligation, or any facts, determined by a tribunal cannot later be put back into question as between the same parties. ${ }^{26}$ In particular, by virtue of the New York Conven-

${ }^{21}$ Broches, A., (1984), pp. 208. It is worth mentioning that in order to be considered as an award under the New York Convention, the award has to comply with the following conditions: (i) the award result from an agreement to arbitrate; (ii) the award must have certain minimal formal characteristics that are inherent to the concept of "award"; and (iii) the award must finally resolve a substantive issue, not a procedural matter.

${ }^{22}$ In this regard, Fouchard, Gaillard and Goldman in Gaillard, E. and Savage, J., (1999), pp. 737, have stated that "an arbitral award can be defined (15) as a final decision by the arbitrators on all or part of the dispute submitted to them, whether it concerns the merits of the dispute, jurisdiction, or a procedural issue leading them to end the proceedings."

23 Born, G., (2014), pp. 2901.

24 Id. at pp. 2901-2902.

25 Id. pp. 2898.

${ }^{26}$ See the award in Amco Asia Corporation v Indonesia (Resubmission: Jurisdiction), ICSID Case No. ARB/81/1, (1992) 89 ILR 552, at 560. 
tion, an arbitral award has preclusive effects generally paralleling those of national court judgments. ${ }^{27}$

In this regard, Professor Born has affirmed that:

"An 'arbitral award', and only an 'arbitral award': (a) has res judicata or other preclusive effect; (b) is subject to being annulled pursuant to national arbitration legislation; (c) is capable of being recognized and enforced under international arbitration conventions and most national arbitration legislations; (d) satisfies requirements in some national arbitration legislation that a final arbitral decision resolving the parties' claims in the arbitration be made within a specified time period; and (e) is required to satisfy form requirements or procedural steps imposed by some arbitration statutes or institutional arbitration rules. Expert determinations, conciliation reports, procedural decisions in an arbitration and other instruments that do not constitute arbitral awards are not subject to these provisions." 28

It is worth mentioning that no arbitral tribunal can be expected to guarantee that its award will be enforceable in whatever country the winner chooses to enforce it. However, every arbitral tribunal must do its best. ${ }^{29}$

\section{Types of arbitration}

\section{a) Commercial arbitration and investment arbitration}

Commercial arbitration involves a dispute between parties acting in their private capacity, mainly international companies, usually based on a commercial contract. The arbitration agreement is embedded in a private contract that regulates the commercial relationship between the companies.

By contrast, investment arbitration involves a dispute between a private investor and a sovereign State, in the sphere of

\footnotetext{
27 Born, G., (2014), pp. 2901.

28 Id. pp. 2901.

29 Blackaby, N. and Partasides, C., (2015), pp. 506.
} 
international investments. It is a type of arbitration in which the private investor and the sovereign State that receives the investment are put at the same level in the resolution of their disputes. In this type of arbitration we do not speak about an arbitration clause but rather of an offer of the recipient State of the investment to the investor to claim an arbitration in case the recipient State does not comply with its international investment obligations (usually provided for in a Bilateral Investment Agreement or Multilateral Investment Agreement). ${ }^{30}$ The offer to arbitrate may also be made either in the host State's national investment law, which often provides for protection of foreign investors or, in certain circumstances, in an investment agreement. The arbitration very often involves a challenge or assessment of the consequences of government policy.

The fact that one of the parties is a sovereign State brings up several consequences of a public nature that spray the private nature of arbitration as a dispute resolution mechanism. Therefore, in investment arbitration there are elements involving both public and private international law.

It is interesting to observe how in investment arbitration the State, rather than acting with its coactive power, plays the role of an additional international commercial actor, in its desire to attract international investment.

\section{b) International arbitration and domestic arbitration}

The arbitration is domestic if all of the following conditions are met:

i. The parties to an arbitration agreement have, at the time of the execution of that agreement, their domiciles in the same State.

ii. The place of arbitration as determined in the arbitration agreement, or pursuant to it, is situated inside the country in which the parties have their domiciles.

30 Cremades, B., (2001), pp. 149-164. 
iii. The place of performance of a substantial part of the obligations of the legal relationship, or the place with which the subject matter of the dispute is most closely connected, is situated inside the national territory, where the parties are domiciled.

On the other hand, an arbitration is international if any of the following circumstances are met:

i. The parties to an arbitration agreement have, at the time of the conclusion of that agreement, their domiciles in different States.

ii. The place of arbitration as determined in the arbitration agreement, or pursuant to it, is situated outside the country in which the parties have their domiciles.

iii. The place of performance of a substantial part of the obligations of the legal relationship, or the place with which the subject the matter of the dispute is most closely connected, is situated outside the national territory, where the parties are domiciled.

\section{c) Ad hoc arbitration and institutional arbitration}

An institutional arbitration exists when a specialized institution, based on the principle of party autonomy, takes on the role of administering the arbitral procedure through its own set of rules which provides a framework for the procedure. The advantage of institutional arbitration is the administrative assistance given by the institution to the parties and the arbitral tribunal. The rules are also very useful to move the arbitration forward in a timely manner.

On the flip side of the coin, ad hoc arbitration is not administered by any institution. Parties will determine directly between themselves all procedural aspects of the arbitration, such as the appointment of the arbitral tribunal, the applicable rules and the timetable for filing submissions. In cases where no procedural rules are agreed, the arbitral tribunal will have discretion to fashion the procedure. 
d) Legal arbitration and ex aequo et bono arbitration

In legal arbitration the framework of the arbitrator's reasoning are the principles and rules of law, usually the law chosen by the parties. In practice the parties normally choose the law of a State, but they can also choose lex mercatoria or a combination of both.

Ex aequo et bono arbitration arises when the arbitral tribunal has the power to decide a dispute in accordance with its sense of fairness and good conscience, instead of rigorously applying terms of a specific body of law.

\section{Actors in International Arbitration}

Following Gaillard's article "Sociology of International Arbitration" we can say that international arbitration constitutes a social field, with its actors and rituals. The following actors can be identified within the international arbitration arena.

\section{a) Essential actors}

The first category of social actors encompasses the actors without which international arbitration would not exist. These essential actors are the parties and the arbitrators. There is no arbitration without parties or without arbitrators, but arbitration can exist without anyone else. ${ }^{31}$

\section{b) Service providers}

The identification of service providers in international arbitration is composed by social groups who dedicate their activity exclusively, or almost exclusively, to international arbitration. ${ }^{32}$ This is the case of counsels, arbitral institutions, States, expert witnesses,

\footnotetext{
31 Gaillard, E., (2015), pp. 4.

${ }^{32}$ Id. pp. 5.
} 
arbitration court reporters, interpreters, or third-party funders, among others.

The International Centre for the Settlement of Investment Disputes, of the World Bank (hereafter "ICSID") and the Permanent Court of Arbitration in the Hague (hereafter "PCA") exemplify the fact that, in certain of their functions, international organizations themselves can also act as service providers with respect to international arbitration. 33

\section{c) Value providers}

The third category of social actors in the international arbitration field is that of value providers. A number of social agents' ambition is to provide guidance as to the way international arbitration should develop and arbitral social actors should behave. ${ }^{34}$ This is the case of States $^{35}$, International Organizations ${ }^{36}, \mathrm{NGOs}^{37}$, arbitration clubs ${ }^{38}$, professional organizations ${ }^{39}$, as well as academic institutions ${ }^{40}$.

${ }^{33}$ Id. pp. 5.

${ }^{34}$ Id. pp. 7.

35 It is undeniable that, for better or for worse, States have a great influence the manner in which arbitration is developed. Gaillard, E., (2015), Gaillard, pp. 7.

${ }^{36}$ International organizations, such as the United Nations Conference on Trade and Development (UNCTAD), the United Nations Commission on International Trade Law (UNCITRAL), and the Organization for Economic Co-operation and Development (OECD), constitute the main fora in which values for international arbitration are expressed. Id. pp. 8.

37 NGOs have penetrated the field of international arbitration as a direct consequence of the exponential growth of investment arbitration. Through amicus curiae briefs, participation in the works of international organizations, numerous publications and aggressive press campaigns, NGOs have promoted values such as the defense of human rights, of the environment, or transparency in the field of investment arbitration. Id. pp. 7 .

38 Arbitration clubs assemble social actors with common characteristics and interests with the view of promoting their own values, such as the International Council for Commercial Arbitration (ICCA) or the International Arbitration Institute. Id. pp. 8-9.

39 Professional organizations, such as the International Bar Association (IBA), play a major role in the field of international arbitration in developing rules or guidelines on a number of features of the international arbitration procedure. Id. pp. 9.

40 Academic institutions specializing in arbitration, such as the Queen Mary School of International Arbitration, the Geneva MIDS programme or the International 
III

\section{ATTEMPTS TO EXPLAIN THE FOUNDATION OF INTERNATIONAL ARBITRATION}

Two important attempts to explain the philosophical foundation of international arbitration have been those of two of the most reputed practitioners in the field of international arbitration, Emmanuel Gaillard and Jan Paulsson. Emmanuel Gaillard with his book Aspects Philosophiques du Droit de L'arbitrage International (in English Legal Theory of Arbitration) $)^{41}$ and his article "Sociology of International Arbitration", already referred to above; and Jan Paulsson with his article "Arbitration in Three Dimensions" 42 and his book The Idea of Arbitration ${ }^{43}$.

It is reassuring and encouraging that these international arbitrators have realized the importance of considering the legal theory and philosophical aspects of international arbitration. It is our belief that intuitively they recognize that international arbitration is wanting of a theoretical framework. Unfortunately, the Austrian School of Economics is not referred to by any of them. With this paper we hope to complete and enrich the work of our predecessors, acknowledging the importance of the Austrian School in the future investigation of international arbitration theory.

Very briefly, we will now underline the main contentions made by Emmanuel Gaillard and Jan Paulsson in each of their works.

On the one hand, in his book, Gaillard distinguishes three different theoretical representations from which to understand arbitration: the monolocal approach, the Westphalian approach, and the transnational approach. Gaillard argues for the latter, i.e. the representation that defends the existence of a transnational arbitration system, an arbitral legal order, which is defined by the consensus among States. According to Gaillard: "The representation

\footnotetext{
Academy for Arbitration Law, and more generally academics focusing on international arbitration, also are value providers as they shape the manner in which arbitration is conducted or perceived through scholarly articles, conferences, and teachings. Id. pp. 9.

41 Gaillard, E. (2010).

42 Paulsson, J., (2011), pp. 291-323.

${ }^{43}$ Paulsson, J. (2013).
} 
that accepts the existence of an arbitral legal order...Far from stigmatizing the alleged inadequacy of national laws, it relies on the notion that the laws of various States, when considered collectively, make up the common rules of arbitration law in which the source of the arbitrators' power to adjudicate is rooted...this representation is not defined in opposition to national laws. Rather, it is entirely based on the normative activity of States." 44 States.

Gaillard's position ultimately rests on the normative activity of

In contrast, we sustain in this paper that international arbitration, the arbitral legal order, has not been created through the constructivist decisions of the States, but is the result of social evolution.

On the other hand, Paulsson strongly criticizes Gaillard's position with regard to the existence of a transnational arbitral legal order. Paulsson defends the so-called revised pluralistic approach as the foundation of arbitration..$^{45}$ According to this thesis, arbitration "derives its legitimacy and effectiveness from an indefinite number of potentially relevant legal orders." ${ }^{\prime 6}$ This revised conception does not depend directly either on law or judges. It does not seek to attach itself to the premise of an autonomous order recognized by the very state orders from which it purports to be free. This model corresponds undeniably to a social institution which is highly effective in practice and it is the most autonomous of all ways of perceiving arbitration, given that it does not depend on national law or courts. ${ }^{47}$ Law must ultimately be founded in social reality. ${ }^{48}$ For Paulsson the purpose of examining this pluralistic environment, in which modern arbitration thrives, is not so much to evaluate it as merely to observe that it exists, that it is ascendant, and that the fluid combination of legal orders in which it operates are not limited to those of the law of States. ${ }^{49}$

\footnotetext{
44 Gaillard, E. (2010), pp. 47-48.

45 Paulsson, J. (2013), pp. 39-48.

46 Paulsson, J., (2011), pp. 291.

47 Paulsson, J. (2013), pp. 45.

48 Id. pp. 46.

49 Paulsson, J., (2011), pp.291.
} 
Paulsson is right when he turns to Santi Romano to establish that the law has its origin in society, and not in the State, and to consider arbitration as a social institution. But he does not refer to the Austrian School of Economics, and therefore does not ultimately anchor arbitration in human action and the theory of the spontaneous evolution of institutions. This prevents him from reaching the conclusion we reach in this paper, i.e. that the foundation and legitimacy of arbitration lie in a dynamic process of social evolution, rather than in the coexistence of a plurality of (sometimes) overlapping legal orders. As stated above Paulsson acknowledges that the purpose of his study is the observance of arbitration as a factual reality, rather than evaluating it from the prism of a theory of arbitration. But observing the practical reality is only part of the task. Arbitration is the direct result of spontaneous evolution, and therefore is framed within the theory of the dynamic evolution of institutions, and based in individual freedom and entrepreneurship. It is only from this theory that we can understand that through arbitration, and the Law that spontaneously evolves in arbitration, we can approach a more advanced and prosperous stage of civilization, based in freedom. ${ }^{50}$

IV

\section{THE SPONTANEOUS MARKET ORDER}

Social order has been understood in different ways in continental Europe and in the Commonwealth tradition, from the XVII century onwards In continental Europe, from a rationalistic and constructivist approach, the idea that social order was constructed or

50 Another attempt at analyzing the fundamentals of international arbitration that is worth mentioning is Dealing in Virtue. International Commercial Arbitration and the Construction of a Transnational Legal Order, Dezalay, Y.; Garth, B.G.; The University of Chicago Press, 1996. In this book arbitration is analyzed from the point of view of spontaneous evolution but from a practical rather than a theoretical perspective. Therefore, no link is expressly made with methodological individualism or the Austrian School of Economics. 
directed by an authority was followed. This idea had a great influence in the development of the different social sciences. ${ }^{51}$

On the other hand in the Commonwealth tradition and in particular starting with the Scottish moral philosophers (Adam Smith, Adam Ferguson and David Hume, among others), the idea that society grows and develops in a non-planned way, but rather through spontaneous evolution based on unaccountable individual decisions taken by each human being in search of his own particular goals and interests, emerged. All of these decisions taken together result in an order that no human mind could be able to plan ${ }^{52}$.

These Scottish authors concluded that progress was not the result of a master plan designed by a person or group of people, and that the emergence and development of social institutions was not the product of any original social contract, but rather that social order progresses through the action of millions of people that while searching their own individual goals achieve as a result the order and welfare of the whole of the society. ${ }^{53}$

This view of society as a product of a spontaneous and evolutionary order passed on to Germany, through the works of Wilhelm von Humboldt and Savigny; and England through Henry Maine; until they reached Carl Menger, the founder of the Austrian School of Economics. According to this view of society a reasonable study of social phenomena should start with the study of the individual and his actions. This assumption is known as Methodological Individualism or praxeology. ${ }^{54}$

An essential characteristic of individualism is that it is primarily a theory of society, i.e. an attempt to understand the forces which determine the social life of man. There is no other way toward an understanding of social phenomena but through our understanding of individual actions directed toward other people and guided by their expected behaviour. ${ }^{55}$

\footnotetext{
51 Rojas, R.M.; (2015), p. 219.

52 Id. p. 219.

53 Id. p. 220.

54 Id. p. 220.

55 Hayek, F.A.; (1948), pp. 6.
} 
Methodological Individualism is the starting point of the Austrian School of Economics in its analysis of the so-called spontaneous market order. ${ }^{56}$ The spontaneous market order is a dynamic process in which by the free exercise of the entrepreneurial function life in society is made possible through the voluntary and spontaneous coordination of the social mismatches. Through this process of social coordination civilization develops in the most harmonious and close-fitting way as is humanly possible in each historical circumstance. ${ }^{57}$

This entrepreneurial process of coordination is never ending. This is because the basic coordinating act consists on discovering, creating and transmitting new information, which at the same time modifies the general perception of objectives and means of all the participants in the process, i.e. the information that exists in the mind of everyone else is constantly changing. Therefore, new mismatches are constantly being discovered or created, that imply new profit opportunities that are open to coordination or adjustment, and this goes on and on. This social process is hence dynamic and transcends each individual human being. ${ }^{58}$

Let us see how this process works in more detail. The process is based in human action and interaction. As already mentioned the methodology of the Austrian School is therefore praxeological and humanistic. ${ }^{59}$ The entrepreneurial function can be defined as consisting on the different market actors discovering the potential profit opportunities around them and acting in consequence, putting the necessary means to take advantage of these opportunities. The information or knowledge of each actor which is relevant for the exercise of the entrepreneurial function is subjective and practical (non-scientific), privative (unique for each individual), disperse (in the minds of all human beings) and tacit (not articulated), created ex nihilo (precisely through the exercise of the entrepreneurial function), and transmissible in an unconscious way through very complex social processes that are precisely the focus

\footnotetext{
56 Hayek, F.A., (2006), pp. 309-336.

57 Huerta de Soto, J., (2012), pp. 49.

${ }^{58}$ Id. pp. 48-51.

59 Id. pp. 117.
} 
of study of Economics, according to the Austrian School authors. With regard to the entrepreneurial function we can say it has the following characteristics. The entrepreneurial function is: (i) essentially creative, the fact of becoming aware or discovering a situation of social discoordination that can result in a profit, based on the unique information the actor has in his mind, does not require any cost, it emerges ex nihilo; and (ii) the entrepreneurial function is competitive in nature, the different actors rivalize and compete in order to detect and take advantage of the potential profit opportunities. ${ }^{60}$

Through the exercise of the entrepreneurial function the actor creates or discovers new information that did not exist before, neither in the actor's mind nor in anyone else's, when he becomes aware of a profit opportunity and acts in consequence. His actions at the same time create new information in the minds of other actors involved or affected by the actor's actions. The new information created in the minds of the different actors is gathered in a compressed and summarized way in the market prices, which reflect the historical relations of exchange between the actors. In this process the different actors learn to discipline their behavior according to the actions of the rest of the actors, and they do so voluntarily, spontaneously and based in freedom, while searching their own interests and objectives (the coordinating effect) ${ }^{61}$.

In order for this process to work properly the different actors that participate in the process have to respect, in a repetitive and constant manner, particular rules of conduct, or rules of Law. These rules are also the result of spontaneous order themselves, and have refined themselves in a spontaneous, evolving and customary way eventually crystalizing into rules of conduct. The Law makes the exercise of human action possible, as well as the emergence and evolution of society and civilization.

The process of spontaneous evolution contrasts starkly with any kind of statism or coercive organization. It is simply impossible that any directing organ can have all the necessary information needed to coordinate social life. This is known as the Impossibility

\footnotetext{
60 Id. pp. 35-51.

61 Id. pp. 45. See also Huerta de Soto, J. (2010), pp.66.
} 
of Socialism Theorem. Firstly, due to the own characteristics of the knowledge or information which is relevant for the exercise of the entrepreneurial function, that, as we have already seen, is of a practical, privative, disperse and tacit nature; therefore, it is impossible to transmit this information to any directing organ. Secondly, because human beings, in the exercise of the entrepreneurial function, constantly create and discover new information that emerges from the social process, and it is not possible to transmit to any directing organ (or anyone) information that does not exist yet. Thirdly, for obvious reasons of the volume of information, which is disseminated in the minds of millions of human beings. Fourthly, because institutional coercion to freedom of action prevents the creation of the information which is precisely required to coordinate social life. Coercion cuts the process of free discovery and coordination of social mismatches, and introduces discoordination and disorder. Moreover, in statism one or a group of objectives is imposed to all, which by definition generates an unsolvable and permanent conflict of interests making social peace impossible. ${ }^{62}$

Social orders, such as international arbitration, or Law, cannot have been created in a planned way by any State, but rather through a spontaneous order based in individual freedom of action.

$\mathrm{V}$

INTERNATIONAL ARBITRATION AS A SPONTANEOUS MARKET ORDER

\section{International Arbitration as an institution of spontaneous evolution}

The view of society from the individual human being and his actions drives to the conclusion that human interaction has

62 Huerta de Soto, J. (2010), pp. 99, 100, 111. 
economic, legal and institutional aspects that make easier both living together and cooperation. Within social sciences Economics is by far the one that has experienced the greatest theoretical development from a praxeological perspective. But the study of society from the individual should also be used as a basis for the study of the Law and the Institutions, as they are aspects of the same phenomenon, society. Unfortunately, this has not been the case. ${ }^{63}$

The Law, as one of the aspects of the social process, is the product of spontaneous rules and free individual decisions. The praxeological basis of human action makes it possible to distinguish the following elements of the Law: (i) contracts; (ii) rules and abstract principles; (iii) institutions. Both the Theory of Contracts and the juridical principles applicable to the solution of disputes, as well as the respective institutions, are the product of a long evolutionary process in which in many occasions particular acts contributed involuntarily to strengthen the final result. ${ }^{64}$

The Law, as an expression of claims, poses the problem of how will these claims be solved. ${ }^{65}$ It is here where arbitration plays a role as an institution that is called to administer justice and solve the disputes that might arise between the different agents acting in the market.

The Law has no link with state power. Both the rules that make communal living possible as well as the process to channel the claims that may arise; are the product of individual decisions and of rules that emerge in a spontaneous evolutionary manner. This same mechanism of spontaneous evolution enables the development of institutions, (such as international arbitration) called on to safeguard compliance of contracts and decisions over the claims. The use of public coactive power to finally enforce the arbitral decisions on the disputes is not a strictly juridical issue, but (again) rather a political one. ${ }^{66}$ In other words, the monopoly of coercive power by the State is a political question, not a juridical one, and falls out of the scope if this article. Our arbitration colleagues

\footnotetext{
63 Rojas, R.M.; (2015), pp. 235, 236.

64 Id. p. 237, 238.

65 Id. p. 241.

66 Id. pp. 244-245.
} 
should bear this in mind before falling into the tempation of thinking that international arbitration exists because of the State structures in place, rather than in spite of them.

International arbitration confirms the postulates of the Austrian School. It is a dispute resolution system that:

- $\quad$ Has been formed spontaneously;

- Is governed by a price system by virtue of which information is transferred to consumers;

- Arbitral actors can act with economic calculation, which allows them to exercise their entrepreneurial function;

- The entrepreneurial function is the protagonist: When disputes are resolved through arbitration, social coordination is achieved in a spontaneous, free and voluntary way;

- Is governed by the principle of consumer sovereignty.

In arbitration the entrepreneurial function is the protagonist: through its exercise, social coordination in the field of justice administration is achieved in a spontaneous, free and voluntary way. Arbitration is a business, which is called to meet one of the most important needs of society: the administration of justice. It is an occupation that is performed by private individuals who discover an opportunity for potential profit in the resolution of disputes. ${ }^{67}$

Each arbitrator has unique and non-transferable information and is therefore able to find its particular niche market. Arbitrators act in constant competition with each other and, consequently, they must be insightful to take advantage of the profit opportunities they discover, putting the necessary means to do so: training, experience, ethics, reputation, etc. Arbitrators are called to perform an abstract intellectual work of law enforcement regardless of the concrete outcome. They comply a really important role in society: They contribute to the respect of the rule of law, thus promoting social peace. ${ }^{6}$

In the marketplace for international arbitration, competition is everywhere: Arbitrators compete for appointments, lawyers

${ }^{67}$ De Benito, M., and Huerta de Soto, S., (2015), pp. 122.
${ }^{68}$ Id. at pp. 123. 
compete for clients, States compete to be designated as arbitral seats, arbitral institutions compete to administer proceedings, experts compete to provide opinions, various arbitration organizations and academics compete to influence developments in the field, third-party funders compete to finance cases, and the parties compete to prevail in the substantive disputes.

It is the constant interaction of all these actors and interests that determines the progressive formation of international arbitration. All of them contribute their grain of sand to create an order as effective as international arbitration that promotes the peaceful settlement of disputes. No one could, by definition, have the intelligence to design an order as complex as international arbitration. Consequently, international arbitration is the result of spontaneous human action, not the result of the execution of any pre-existing human design nor the result of any decision of the State.

In the words of Benson:

"Commerce and commercial law have developed conterminously, without the aid of and often despite the interferences of the coercive power of nation-states because there is a mechanism in place. Commercial law itself is analogous to the price system in that it facilitates interaction and makes exchange more efficient. Commercial law develops directly from the market exchange process as business practice and custom evolves." 69

Just as competition enables discovery and innovation in markets, competition enables discovery and innovation in law too. ${ }^{70}$ Centralized law enforcement faces knowledge and accountability problems similar to those of central economic planners. But in a system in which people are allowed to select from many competing providers of law, individuals can have the set of rules and enforcement procedures that they actually value. ${ }^{71}$

Something fascinating about international arbitration is that, despite its inherent diversity, everyone speaks in the same code.

\footnotetext{
69 Benson, B., (1989), pp. 645.

70 Zywicki, T.J.; Stringham, E.P. (2017), pp. 18.

71 Id. pp. 19.
} 
Nationality, culture, religion, ethnicity or language are absolutely irrelevant. South American lawmakers did not sit down to negotiate with Asian lawmakers to make international arbitration work in the same way in both continents. That was a gift of spontaneous order.

The formation of international arbitration is not far from the formation of language, traffic rules, family, the market economy, the price system, money, and so on. All of these institutions are, mutatis mutandi, formed by the same evolutionary and spontaneous process.

It is not a coincidence that it is in the international arena where arbitration has developed most vigorously. It is undeniable that in the international sphere there is greater freedom for the exercise of the business function, because the coercive power of States is limited. Without the presence of coercive mandates, States are constrained to cooperate peacefully seeking to attract investments. ${ }^{72}$

Praxeology, therefore, as the science that studies the evolution and logic of human action, is the only methodology that can explain international arbitration integrally. The Austrian School of Economics is the only school of thought that has developed a comprehensive theoretical analysis of evolutionary and spontaneous social processes based in human action that can explain the foundations of international arbitration from an appropriate and coherent approach.

\section{Examples of spontaneous evolution in arbitration}

Not only is international arbitration an institution of social evolution itself but we can find different manifestations of spontaneous order within it.

One of the most important manifestations of spontaneous order in international arbitration can be observed in the emergence of rules of law, that have not been created by any State or directing organ, but are the direct result of the dynamic process of social evolution. These rules can be observed in two specific areas:

72 De Benito, M., and Huerta de Soto, S., (2015), pp. 123. 


\section{a) Procedural Rules in International Commercial Arbitration}

In international commercial arbitration there are numerous arbitral institutions worldwide (for example, London Court of International Arbitration, International Court of Arbitration of the International Chamber of Commerce in Paris, International Court of Arbitration of the Stockholm Chamber of Commerce, and from the beginning of 2020 the International Arbitration Centre of Madrid, among many others), that compete with each other to attract arbitrations. In order to do so they have to offer certainty, professionalism, efficiency and competitive prices to the parties. The Procedural Rules of the different institutions are a very strong instrument of competition. The institutions try to offer the best procedural rules, in order for the arbitration to be conducted in the best way possible keeping the costs as low as possible. It is interesting to observe how as a result of the own dynamics of international commercial arbitration these procedural rules have converged naturally to the point that they are all quite similar. Differences still exist, and will always exist, as each arbitral institution has its own particularities and seeks to differentiate from the rest, but we can say that the arbitration procedure has been standardized to a great extent, no matter where the parties come from or what the arbitral institution is.

In addition to the procedural rules of the arbitral institutions there are other procedural rules that have emerged from the practice of arbitration and which have become common practice: IBA Rules on the practice of evidence ${ }^{73}$, for example, are the result of a working group of professionals gathered under the auspices of the International Bar Association (the largest international association of lawyers worldwide) and are applied daily by the parties and the arbitrators in the arbitration procedure.

The parties to the arbitration, in particular the lawyers to the parties, have contributed to a great extent to the standardization of the arbitral process. In arbitration the principle of party autonomy reigns. The parties are the ones that choose what procedure their arbitration will follow, be it indirectly by choosing a specific arbitral institution

${ }^{73}$ IBA Rules on the taking of evidence in International Arbitration, 2010. 
(and its rules), be it directly, usually in the First Procedural Order issued by the Arbitral Tribunal at the beginning of the arbitral procedure, where the parties and the Arbitral Tribunal agree on the specific procedural rules to be applied during the arbitration.

These rules have not been created by any hierarchically superior organ but are the result of the practice of arbitral tribunals, lawyers, parties, and private organizations that in their daily business make many decisions in millions of different arbitrations.

\section{b) Substantive Rules in International Investment Arbitration}

In investment arbitration, not only the spontaneous emergence of procedural rules can be observed, but also of substantive rules. This is a phenomenon that is taking place every day in arbitral practice, and today we can talk about the new lex mercatoria, or in other words the law of investment arbitration. The spontaneous process of formation of investment law is complex.

Bilateral and multilateral investment treaties recognize several standards of protections to the investor. The treaties are normally very concise when defining these standards and it is through arbitral jurisprudence and doctrine that these standards have been provided of substantive content. Investment law is a dynamic institution in constant evolution, which is captured at a given point in time in an international treaty, but which is subject to constant revision and refinement through practice (application and interpretation of the treaties by the arbitral tribunals and doctrinal analysis).

When the State signs and ratifies an investment treaty, it is acting as one more actor of the international investment arena, along with the rest of the states, the investors and the arbitral tribunals, but not as a directing organ. Investment treaties recognize almost invariably the following standards of protection: Expropriation, Fair and Equitable Treatment, National Treatment, Most Favoured Nation Treatment, and Full Protection and Security.

One debate that arises in investment arbitration tribunals is the potential relation between the standards of protection of bilateral and multilateral investment treaties and customary international law. In particular, the question is if part of the content of these 
standards (some of their elements) can be considered as part of the minimum standard of treatment of customary international law. ${ }^{74}$

From an Austrian perspective, a potential relation between the standards of protection and customary international law is obvious: (i) they are both Law, (ii) in the sphere of international investment relations, (iii) that results from the same process of spontaneous evolution. Investment law emerges from a process of spontaneous and dynamic evolution, as does customary international law. Therefore, we believe that we are not talking about different legal concepts, but rather each might be expressing a different stage of evolution of the same Law, investment law. In this sense the standards of protection have elements that can already be considered as part of customary international law, and at the same time customary international law is a dynamic legal concept which is in constant evolution. The application and interpretation of the standards of protection by the arbitral tribunals contributes to this evolution of customary international law. And arbitral tribunals apply customary international law to give effect, content and life to the standards of protection.

\section{VI CONCLUSION}

The Austrian paradigm offers the theoretical framework under which International Arbitration must be understood, studied and analyzed. What is more, the Austrian School offers the only

74 This debate arose for example in the Windstream Energy LLC v. Governement of Canada case, under Chapter 11 NAFTA, and 2010 UNCITRAL Arbitration Rules, administered by the Permanent Court of Arbitration, See Award dated September 27 th, 2016, paras. 355, 356, 377, 378, 379. In this case the main question before the Tribunal was whether the element of legitimate expectations of the investor, which is a well established element of the Fair and Equitable Treatment Standard ("FET standard") could be considered as part of the minimum standard of treatment of customary international law. Although the Arbitral Tribunal avoided any express reference to legitimate expectations, after analyzing the facts alleged by the Claimant to be a breach of its legitimate expectations, concluded that Canada had breached the FET standard in article 1105 (1) and hence the minimum standard of treatment. The Arbitral Tribunal interpreted the content of the minimum standard of treatment based on the specific wording of NAFTA article 1105 (1). 
theoretical principles under which International Arbitration can be correctly interpreted, and at the same time arbitration erects itself as an undisputable practical reality that illustrates the theory of the Austrian School in the field of the administration of justice.

It is of vital importance to link arbitration to the principles of the Austrian School in order to fully understand where the institution of arbitration comes from, where it is at the present moment and what its future should be, in order to keep advancing in the path that leads to a more fair, prosperous and free society. Not doing so can have perverse effects and can put the institution at risk.

As an example of this institutional risk we may refer to the over 40 investment arbitrations against Spain in the energy sector. Spain's change of legislation in the energy sector in 2013 and 2014 cancelling the public aid initially offered to the investors in the renewable energy sector has provoked a waterfall of investment claims against Spain in the last years.

These arbitrations put at stake the alleged public interest vs. the investment standard of Fair and Equitable Treatment, in particular its element known as the 'legitimate expectations' of the investor.

The arbitral tribunals sitting in these arbitrations are directly involved in the definition of the content and extent of the Fair and Equitable Treatment standard of protection. It is of vital importance that the extent and content given in these arbitrations to the Fair and Equitable Treatment standard is the appropriate one and that the issues in these arbitrations are addressed from an appropriate legal theory of arbitration.

The public aids of the State in the Spanish renewable energy sector have distorted the energy market, erroneous messages have been sent to the investors regarding the profitability of the renewable energy sector. These investors have erroneously invested accordingly in a market sector that is not in fact profitable because there is no real demand for it. In other words, these investments are not backed up by any real savings. This generates a distortion in the economy that cannot be sustained in the long term and which the market tends to correct. It is therefore a social, economic and legal obligation to limit and discipline the distorting actions of the State in the economy from every angle, including from the angle of investment law and arbitration. 
Through the standard of legitimate expectations the arbitral tribunals in these cases should deter and restrict the State from adopting legislation that has distorting effects on the economy and at the same time foster the compliance of contractual commitments. In order to do this it is key to keep the State on a short leash so it knows that it shall respect its commitments towards investors, without opening the hand in favour of an ambiguous and opportunistic concept such as public interest, which should be restricted to the extent possible.

If the concept of legitimate expectations easily gives in in favour of the purported power of the State to regulate or in favour of the concept of public interest, without any juridical consequences for the State, we run the risk of encouraging the State to keep acting in a distorting way and not to faithfully comply with its contractual commitments, which does not favour either the investor, the economy or society.

In the case of these energy arbitrations, it was a fatal error for the State to pass on legislation offering public aids to investors in order to attract investments in the renewable energy sector. These investments were made without any backing of real savings and were not sustainable in the long term. The Spanish State eventually realized this and unilaterally changed its legislation, removing the aids initially offered, but the investments had already been made. Who has to pay for these erroneous decisions of investment? In our opinion it is the State the one which should be made responsible for the erroneous economic consequences of its own legislation, not the investors. This is the only way to deter the State from passing on 'investment attracting' legislation that gravely distorts the economy. ${ }^{75}$

75 From a strict Methodological Individualism point of view the State has no juridical personality of its own and could not be condemned to pay any compensation to the investor. The Spanish State cannot promise, grant or cancel subsidies, only particular politicians and officials do. De lege ferenda this is correct. According to the Austrian School of Economics, the State should in fact disappear or at least be reduced to its minimum expression. Nevertheless, it is undeniable that as for today the State does exist and it is a well established principle in all national juridical systems that the State has independent juridical personality. It is therefore from a de lege lata perpective that our analysis should be considered. 
We can see how important it is for these arbitral tribunals to understand the Austrian framework in which arbitration operates. It is the only way for arbitration to move forward toward a more free, prosperous and fair economy and society. Without the Austrian theory reference these arbitral tribunals can easily get lost in a melting pot of juridical technicalities losing the bigger picture of the role of arbitration in the economy and in social life.

Finally, we consider this paper is a contribution not only to the arbitral community, which is wanting of a theoretical backbone that can solidly sustain the institution of arbitration, but also to the Austrian School of Economics itself as it applies the Austrian theory of the evolution of institutions to a completely new field, which is that of the administration of justice, the field of arbitration. This is an unexplored field with an enormous potential for investigation for the Austrian School of Economics.

\section{BIBLIOGRAFICAL REFERENCES}

Blackaby, N. and Partasides, C., (2015): Redfern and Hunter on International Arbitration, 6th edition, Oxford University Press.

Benson, B.L., (1989): “The Spontaneous Evolution of Commercial Law", Southern Economic Journal, Vol. 55, pp. 644-661.

Born, G., (2014): International Commercial Arbitration, 2nd edition, Wolters Kluwer Law \& Business.

Broches, A., (1984): "Recourse against the award; Enforcement of the award", ICCA Congress Series: UNCITRAL's Report for a Model Law on International Commercial Arbitration (P. Sanders, ed.), Congress Series $n^{\circ} 2$, pp. 201-228.

Cremades, B., (2001): "Arbitration in Investment Treaties: public offer of arbitration in investment-protection treaties", Law of International Business and Dispute Settlement in the 21st Century, Liber Amicorum, Karl-Heinz Böckstiegel, Briner, R., (ed.), Alemania: Heymanns, pp. 149-164.

Cuniberti, G., (2009): "Beyond Contract. The Case for Default Arbitration in International Commercial Disputes", Fordham International Law Journal, Vol. 32, pp. 417-488. 
de Benito, M., and Huerta de Soto, S., (2015): “El Arbitraje Internacional como Orden Jurídico Espontáneo", Spain Arbitration Review, n'. 22, pp. 113-127.

de Vries, (1982): “International Commercial Arbitration: A Contractual Substitute for National Courts", Vol. 57 Tulane Law Review pp. 42-79.

Dezalay, Y.; Garth, B.G., (1996) Dealing in Virtue. International Commercial Arbitration and the Construction of a Transnational Legal Order, The University of Chicago Press.

di Pietro, D., (2008), "What Constitutes an Arbitral Award Under the New York Convention?", Enforcement of Arbitration Agreements and International Arbitral Awards: The New York Convention in Practice, Gaillard E., Di Pietro, D., (eds.), pp. 139-155.

Gaillard, E. and Savage, J., (1999): Fouchard, Gaillard, Goldman on International Commercial Arbitration, Kluwer Law International.

Gaillard, E., (2015): "Sociology of International Arbitration", Arbitration International, Oxford Academic, Vol. 31, Issue 1, pp. 1-17.

- (2008): Legal Theory of Arbitration, Martinus Nijhoff Publishers, (2010).

Hayek, F.A., (Rules and Order, 1973; The Mirage of Social Justice, 1976, The Political Order of a Free People, 1979): Derecho, legislación y libertad, Unión Editorial, 2006.

- (1948): "Individualism: True and False", Individualism and Economic Order, The University of Chicago Press

Huemer, M., (2019): El problema de la autoridad política, Instituto Juan de Mariana, Value School, Ediciones Deusto.

Huerta de Soto, J., (2010): Socialismo, cálculo económico y función empresarial, Unión Editorial

- (2012): La Escuela Austriaca, mercado y creatividad empresarial, Editorial Síntesis.

Paulsson, J., (2011): "Arbitration in three dimensions", International and Comparative Law Quarterly, Vol. 60, Issue 1, pp. 291-323.

- (2013): The Idea of Arbitration, Oxford University Press.

Poudret, J. \& Besson, S., (2007): Comparative Law of International Arbitration, $2^{\text {nd }}$ ed.,Sweet \& Maxwell.

Reisman, W., Craig, L., Park, W., \& Paulsson, J., (1997): International Commercial Arbitration. Cases, Materials, and Notes on the Resolution of International Business Disputes, Foundation Press. 
Rojas, R.M., (2015): "Fundamentos praxeológicos del Derecho", Revista de estudios de Justicia, Derecho y Economía (RJDE), No. 2 Enero-Junio, pp. 217-245.

Tannehill, M.; Tannehill, L., (2011): “Arbitration of Disputes", Mises Institute; July 1.

Van Den Berg, A., (1994): The New York Convention 1958: Towards a Uniform Judicial Interpretation, Kluwer Law International.

Zywicki, T.J.; Stringham, E.P., (2017): “Austrian Law and Economics and Efficiency in the Common Law", Research Hanbook on Austrian Law and Economics, edited by Zywicki, T.J.; and Boettke, P.J.; Edward Elgar Publishing. 
